\title{
Parapedobacter koreensis gen. nov., sp. nov.
}

Correspondence

Deok-Chun Yang

deokchunyang@yahoo.co.kr

\author{
Myung Kyum Kim, ${ }^{1}$ Ju-Ryun $\mathrm{Na},{ }^{1}$ Dong Ha Cho, ${ }^{2}$ Nak-Kyun Soung ${ }^{3}$ \\ and Deok-Chun Yang ${ }^{1}$
}
${ }^{1}$ Department of Oriental Medicinal Material and Processing, College of Life Science, Kyung Hee University, 1 Seocheon-dong, Kiheung-gu Yongin, Kyunggi-do 449-701, South Korea
${ }^{2}$ Kangwon National University, School of Bioscience and Biotechnology, Chunchon 200-701, South Korea
${ }^{3}$ Laboratory of Metabolism, Center for Cancer Research, National Cancer Institute, NIH, Bethesda, MD 20892, USA

\begin{abstract}
Strain Jip $14^{\top}$, a Gram-negative, non-spore-forming, rod-shaped, non-motile bacterium, was isolated from dried rice straw and characterized in order to determine its taxonomic position. 16S rRNA gene sequence analysis revealed that strain Jip $14^{\top}$ belongs to the family Sphingobacteriaceae, and the highest degree of sequence similarity was determined to be to Pedobacter saltans DSM $12145^{\top}$ (88.5\%), Pedobacter africanus DSM $12126^{\top}$ (87.6\%), Pedobacter heparinus DSM $2366^{\top}$ (87.1\%) and Pedobacter caeni LMG $22862^{\top}$ (86.9\%). Chemotaxonomic data revealed that strain Jip $14^{\top}$ possesses menaquinone MK-7 and the predominant fatty acids $\mathrm{C}_{15: 0}$ iso, $\mathrm{C}_{16: 0}, \mathrm{C}_{16: 0}$ 10-methyl, $\mathrm{C}_{17: 0}$ iso 3-OH and summed feature $3\left(\mathrm{C}_{15: 0}\right.$ iso $\left.2-\mathrm{OH} / \mathrm{C}_{16: 1} \omega 7 \mathrm{c}\right)$. The results of physiological and biochemical tests clearly demonstrated that strain Jip $14^{\top}$ represents a distinct species. Based on these data, Jip $14^{\top}$ should be classified within a novel genus and species, for which the name Parapedobacter koreensis gen. nov., sp. nov. is proposed. The type strain of Parapedobacter koreensis is $\operatorname{Jip} 14^{\top}\left(=\right.$ KCTC $12643^{\top}=$ LMG $\left.23493^{\top}\right)$.
\end{abstract}

The family Sphingobacteriaceae was proposed by Steyn et al. (1998). Typical features of the family Sphingobacteriaceae are the possession of sphingolipids, the presence of the MK-7 quinone system, a relatively low $\mathrm{G}+\mathrm{C}$ content (37-44 mol\%) and a unique fatty acid profile (including $\mathrm{C}_{15: 0}$ iso, $\mathrm{C}_{15: 0}$ iso $2-\mathrm{OH}$ and $\mathrm{C}_{15: 0}$ iso $\left.3-\mathrm{OH}\right)$. At present, the family Sphingobacteriaceae includes two genera, Pedobacter and Sphingobacterium. The genus Sphingobacterium was established by Yabuuchi et al. (1983) with three species, Sphingobacterium spiritivorum (originally Flavobacterium spiritivorum), S. mizutaii and S. multivorum. At present, following the reclassification of two species to Pedobacter, the genus Sphingobacterium includes another four accepted species, Sphingobacterium antarcticum (Shivaji et al., 1992), Sphingobacterium faecium, Sphingobacterium (Flavobacterium) thalpophilum (Takeuchi \& Yokota, 1992) and Sphingobacterium daejeonense (Kim et al., 2006). The genus Pedobacter was proposed by Steyn et al. (1998) with the reclassification of two Sphingobacterium species as Pedobacter heparinus and Pedobacter piscium and the description of two novel species, Pedobacter africanus and Pedobacter saltans. Subsequently, Pedobacter cryoconitis (Margesin et al., 2003), Pedobacter himalayensis (Shivaji et al., 2005),

The GenBank/EMBL/DDBJ accession number for the $16 \mathrm{~S}$ rRNA gene sequence of strain Jip $14^{\top}$ is DQ680836.
Pedobacter caeni (Vanparys et al., 2005), Pedobacter aquatilis (Gallego et al., 2006), Pedobacter ginsengisoli (Ten et al., 2006), Pedobacter sandarakinus (Yoon et al., 2006), Pedobacter roseus (Hwang et al., 2006), Pedobacter panaciterrae (Yoon et al., 2007) and Pedobacter suwonensis (Kwon et al., 2007) have been described. Data for these last six recently described species were not available for comparison at the time of writing.

In a series of studies, we attempted to isolate microorganisms from dried straw in order to investigate the community structure based on a culture-dependent method. In this study, strain Jip $14^{\mathrm{T}}$ was isolated from dried rice straw in a field in Daejeon city in South Korea and characterized by a polyphasic approach, including phylogenetic analysis based on 16S rRNA gene sequences, genomic relatedness and chemotaxonomic and phenotypic properties. The results obtained in this study indicated that strain Jip $14^{\mathrm{T}}$ can be assigned as a member of the family Sphingobacteriaceae within a novel genus and species.

Strain Jip $14^{\mathrm{T}}$ was isolated from dried rice straw via direct plating onto R2A agar (Difco). Single colonies on these plates were purified by transferring them onto new plates and subjecting them to additional incubation for 5 days at $30{ }^{\circ} \mathrm{C}$. The purified colonies were tentatively identified by using partial $16 \mathrm{~S}$ rRNA gene sequences. 
Cell morphology and motility were observed with a Nikon light microscope $(\times 1000$ magnification $)$, with the cells being allowed to grow for 3 days at $30^{\circ} \mathrm{C}$ on R2A agar. The Gram reaction was examined according to the non-staining method (Buck, 1982). Oxidase activity was evaluated via the oxidation of $1 \% p$-aminodimethylaniline oxalate. Catalase activity was determined by measurements of bubble production after the application of $3 \%(\mathrm{v} / \mathrm{v}) \mathrm{H}_{2} \mathrm{O}_{2}$ solution. Acid production from carbohydrates was assessed by the procedures outlined by Cappuccino \& Sherman (2002). Growth at $4,15,25,30,37$ and $42^{\circ} \mathrm{C}$ was assessed on R2A agar and growth at various $\mathrm{pH}$ values was assessed in $\mathrm{R} 2 \mathrm{~A}$ broth. Growth was also evaluated at $30^{\circ} \mathrm{C}$ on nutrient agar (NA), trypticase soy agar (TSA) and MacConkey agar. The API 20NE and API ID32 GN microtest systems were employed according to the recommendations of the manufacturer (bioMérieux).

Isoprenoid quinones were extracted with chloroform/ methanol $(2: 1, \mathrm{v} / \mathrm{v})$, purified via TLC and subsequently analysed by HPLC as described previously (Collins \& Jones, 1981; Shin et al., 1996). In order to perform fatty acid methyl ester analysis, the strain was allowed to grow on TSA for $48 \mathrm{~h}$ at $30^{\circ} \mathrm{C}$ and then two loops of well-grown cells were harvested. Fatty acid methyl esters were prepared, separated and identified with the Sherlock Microbial Identification System (MIS) (Sasser, 1990). Polyamines were extracted and analysed according to Busse \& Auling (1988) and Schenkel et al. (1995), respectively. Polar lipids were extracted and examined by using two-dimensional TLC (Minnikin et al., 1984).

The genomic DNA of strain Jip $14^{\mathrm{T}}$ was extracted and purified with the Qiagen Genomic-tip system 100/G and was then enzymically degraded into nucleosides as described previously (Tamaoka \& Komagata, 1984; Mesbah et al., 1989).

Genomic DNA was extracted and purified with the Genomic DNA isolation kit (Core Bio System). The 16S rRNA gene was amplified from chromosomal DNA of strain Jip $14^{\mathrm{T}}$ using the universal bacterial primers $9 \mathrm{~F}$ and $1512 \mathrm{R}$ (Weisburg et al., 1991) and the purified PCR products were sequenced by Genotec (Daejeon, Korea) (Kim et al., 2005). The full sequence of the $16 \mathrm{~S}$ rRNA gene was compiled with SeqMan software and the 16S rRNA gene sequence of the test strain was edited using the BioEdit program (Hall, 1999). The 16S rRNA gene sequences of related taxa were obtained from GenBank and multiple alignments were performed with the CLUSTAL X program (Thompson et al., 1997). Evolutionary distances were calculated using the Kimura two-parameter model (Kimura, 1983). The phylogenetic tree was constructed via the neighbour-joining method (Saitou \& Nei, 1987) in the MEGA2 program (Kumar et al., 2001). Bootstrap analysis with 1000 replicates was also conducted in order to obtain confidence levels for the branches (Felsenstein, 1985). All species of the genera Pedobacter and Sphingobacterium were included in the phylogenetic tree.
Strain Jip $14^{\mathrm{T}}$ was cultured on R2A agar (Difco) at $30^{\circ} \mathrm{C}$, yielding white, circular colonies. Strain Jip $14^{\mathrm{T}}$ was found to be an aerobic, Gram-negative, non-motile and rod-shaped bacterium. Strain Jip $14^{\mathrm{T}}$ was also determined to be able to grow at $25-42^{\circ} \mathrm{C}$, but did not grow at $4{ }^{\circ} \mathrm{C}$. Growth at $37^{\circ} \mathrm{C}$ was not observed on MacConkey agar. Physiological characteristics of strain Jip $14^{\mathrm{T}}$ are summarized in the species description and a comparison of differential characteristics with related type strains is shown in Table 1.

Strain Jip $14^{\mathrm{T}}$ was similar to members of the family Sphingobacteriaceae in that it was a Gram-negative, non-motile, aerobic, non-spore-producing, oxidase- and catalasepositive, rod-shaped bacterium. Strain Jip $14^{\mathrm{T}}$ has properties similar to those of species of the genus Pedobacter in that it has no urease or $\alpha$-mannosidase activity. In contrast to species in the genera Pedobacter and Sphingobacterium, strain Jip $14^{\mathrm{T}}$ utilizes inositol as a sole carbon source and does not have esterase activity.

The cellular fatty acid profiles of strain Jip $14^{\mathrm{T}}$ and related Pedobacter and Sphingobacterium type strains are shown in Table 2. The major cellular fatty acids in strain Jip $14^{\mathrm{T}}$ included $\mathrm{C}_{15: 0}$ iso (33.6\%), $\mathrm{C}_{16: 0}(6.0 \%), \mathrm{C}_{16: 0}$ 10-methyl $(7.1 \%), \mathrm{C}_{17: 0}$ iso $3-\mathrm{OH}(14.4 \%)$ and summed feature 3 $\left(\mathrm{C}_{15: 0}\right.$ iso $\left.2-\mathrm{OH} / \mathrm{C}_{16: 1} \omega 7 c ; 27.8 \%\right)$. Minor amounts of $\mathrm{C}_{14: 0}(1.1 \%), \mathrm{C}_{16: 0}$ anteiso (0.5\%), $\mathrm{C}_{15: 1} \omega 6 c(1.0 \%), \mathrm{C}_{15: 0}$ $3-\mathrm{OH}(1.7 \%), \mathrm{C}_{15: 0}$ iso $3-\mathrm{OH}(2.3 \%), \mathrm{C}_{16: 0} 2-\mathrm{OH}(1.1 \%)$ and $\mathrm{C}_{16: 0} 3-\mathrm{OH}(1.9 \%)$ were also present. The fatty acid profile of strain Jip $14^{\mathrm{T}}$ is different from those of members of related genera. There are a number of qualitative differences; for instance, strain Jip $14^{\mathrm{T}}$ has no $\mathrm{C}_{16: 1} \omega 5 c$ or $\mathrm{C}_{17: 1}$ iso $\omega 9 c$. These fatty acids are common to Pedobacter species but absent in Sphingobacterium.

Strain Jip $14^{\mathrm{T}}$ contained a menaquinone with seven isoprene units (MK-7) as the predominant isoprenoid quinine. Menaquinone MK-7 is commonly found in species in the family Sphingobacteriaceae (Steyn et al., 1998). The major polyamine of strain Jip $14^{\mathrm{T}}$ was homospermidine, as is the case for other species in the family Sphingobacteriaceae. Sphingolipid, which is a characteristic feature of the family Sphingobacteriaceae, was also detected.

The $16 \mathrm{~S}$ rRNA gene sequence of strain Jip $14^{\mathrm{T}}$ was found to be a continuous stretch of 1481 nucleotides. Strain Jip $14^{\mathrm{T}}$ was determined to belong to the class Sphingobacteria, order Sphingobacteriales and family Sphingobacteriaceae. The highest degrees of sequence similarity were found with Pedobacter saltans DSM $12145^{\mathrm{T}}(88.5 \%)$, Pedobacter africanus DSM $12126^{\mathrm{T}}(87.6 \%)$, Pedobacter heparinus DSM $2366^{\mathrm{T}}(87.1 \%)$ and Pedobacter caeni LMG $22862^{\mathrm{T}}$ $(86.9 \%)$. In the phylogenetic tree (Fig. 1), strain Jip $14^{\mathrm{T}}$ clearly belonged to the family Sphingobacteriaceae lineage, as evidenced by the high bootstrap value. Based on 16S rRNA gene sequencing, the phylogenetic position of strain Jip $14^{\mathrm{T}}$ among members of the family Sphingobacteriaceae was unique and distinct. 
Table 1. Differential phenotypic characteristics between strain Jip $14^{\top}$, Pedobacter species and other related species

Strains: 1, strain Jip14 ${ }^{\mathrm{T}} ; 2$, Pedobacter africanus LMG $10353^{\mathrm{T}} ; 3$, Pedobacter caeni LMG 22862 ${ }^{\mathrm{T}} ; 4$, Pedobacter cryoconitis DSM $14825^{\mathrm{T}}$; 5 ,

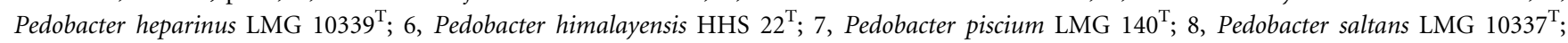

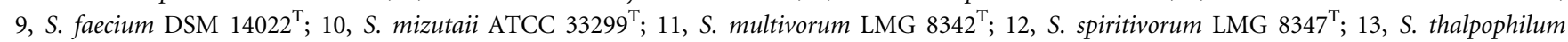
LMG $11520^{\mathrm{T}}$. +, Positive; -, negative; V, variable; ND, no data available. Data for reference Pedobacter strains, with the exception of Pedobacter caeni LMG $22862^{\mathrm{T}}$ (data from Vanparys et al., 2005), were taken from Shivaji et al. (2005); data for reference Sphingobacterium strains were taken from Steyn et al. (1998).

\begin{tabular}{|c|c|c|c|c|c|c|c|c|c|c|c|c|c|}
\hline Characteristic & 1 & 2 & 3 & 4 & 5 & 6 & 7 & 8 & 9 & 10 & 11 & 12 & 13 \\
\hline Gliding motility & - & - & + & + & + & - & - & - & - & - & - & - & - \\
\hline Optimum growth temperature $\left({ }^{\circ} \mathrm{C}\right)$ & 37 & 37 & 37 & 25 & 37 & 25 & $25-30$ & $25-30$ & $\mathrm{ND}$ & ND & ND & $\mathrm{ND}$ & ND \\
\hline Growth at $37^{\circ} \mathrm{C}$ & + & $\mathrm{V}$ & + & $\mathrm{ND}$ & $\mathrm{V}$ & $\mathrm{ND}$ & - & $\mathrm{V}$ & + & + & + & + & + \\
\hline Nitrate reduction & - & - & - & - & - & - & - & - & - & - & - & - & + \\
\hline \multicolumn{14}{|l|}{ Enzyme activities } \\
\hline$N$-Acetyl- $\beta$-glucosaminidase & + & + & - & + & + & + & + & + & + & + & + & + & + \\
\hline Arginine dihydrolase & - & - & - & - & - & + & ND & - & $\mathrm{ND}$ & ND & $\mathrm{ND}$ & $\mathrm{ND}$ & ND \\
\hline Esterase (C8) & - & + & + & + & + & + & + & + & + & + & + & + & + \\
\hline$\alpha$-Glucosidase & + & + & - & + & + & + & + & + & + & + & + & + & + \\
\hline$\beta$-Glucosidase & + & $\mathrm{V}$ & + & + & - & + & + & + & + & + & + & + & + \\
\hline$\beta$-Glucuronidase & - & $\mathrm{ND}$ & - & $\mathrm{ND}$ & ND & $\mathrm{ND}$ & ND & ND & $\mathrm{V}$ & - & $\mathrm{V}$ & + & + \\
\hline Lipase & - & + & + & - & - & - & $\mathrm{V}$ & + & $\mathrm{V}$ & + & $\mathrm{V}$ & + & - \\
\hline$\alpha$-Mannosidase & - & - & - & $\mathrm{ND}$ & ND & ND & ND & ND & + & + & + & + & + \\
\hline Protease & - & $\mathrm{V}$ & - & + & - & + & - & - & - & - & $\mathrm{V}$ & - & - \\
\hline Urease & - & - & - & - & - & - & - & - & + & + & + & + & + \\
\hline Valine arylamidase & + & ND & - & $\mathrm{ND}$ & $\mathrm{ND}$ & $\mathrm{ND}$ & ND & $\mathrm{ND}$ & + & + & + & + & + \\
\hline Growth on MacConkey agar & - & - & ND & - & - & + & - & - & $\mathrm{ND}$ & ND & ND & $\mathrm{ND}$ & ND \\
\hline Glucose fermentation & + & + & - & - & + & - & + & $\mathrm{V}$ & + & + & + & + & + \\
\hline \multicolumn{14}{|l|}{ Assimilation tests } \\
\hline Acetate & - & - & ND & - & - & - & - & - & - & - & - & - & - \\
\hline Caprate & - & ND & - & ND & $\mathrm{ND}$ & ND & ND & $\mathrm{ND}$ & - & - & - & - & - \\
\hline Citrate & - & - & - & - & - & - & - & - & - & $\mathrm{V}$ & - & - & - \\
\hline L-Arabinose & - & $\mathrm{V}$ & + & $\mathrm{ND}$ & + & ND & + & + & + & $\mathrm{V}$ & + & - & + \\
\hline L-Fucose & + & $\mathrm{V}$ & - & + & + & + & - & - & - & - & - & - & - \\
\hline D-Glucose & + & - & + & + & - & + & - & + & + & + & + & + & + \\
\hline Maltose & + & $\mathrm{V}$ & + & + & + & + & + & + & + & + & + & + & + \\
\hline Melibiose & - & + & + & + & + & + & + & $\mathrm{V}$ & + & + & + & + & + \\
\hline L-Rhamnose & - & + & - & - & + & + & $\mathrm{V}$ & + & $\mathrm{ND}$ & ND & $\mathrm{ND}$ & $\mathrm{ND}$ & ND \\
\hline Ribose & + & $\mathrm{V}$ & - & - & - & + & - & - & - & - & - & - & - \\
\hline Sucrose & + & + & + & + & + & + & + & $\mathrm{V}$ & + & + & + & + & + \\
\hline Inositol & + & - & - & - & - & - & - & - & - & - & - & - & - \\
\hline Mannitol & + & - & - & - & + & + & - & - & - & - & - & + & - \\
\hline Sorbitol & + & - & - & - & + & + & - & - & - & - & - & - & - \\
\hline L-Alanine & - & $\mathrm{V}$ & ND & - & - & + & - & - & $\mathrm{ND}$ & ND & ND & $\mathrm{ND}$ & ND \\
\hline L-Histidine & - & $\mathrm{V}$ & $\mathrm{ND}$ & - & - & - & - & - & - & + & $\mathrm{V}$ & - & - \\
\hline L-Proline & - & $\mathrm{V}$ & ND & - & - & + & + & - & - & + & - & - & - \\
\hline L-Serine & + & + & ND & - & $\mathrm{V}$ & + & $\mathrm{V}$ & - & - & V & - & - & - \\
\hline$N$-Acetyl-D-glucosamine & + & + & + & + & + & + & + & + & $\mathrm{ND}$ & ND & ND & $\mathrm{ND}$ & ND \\
\hline Salicin & + & $\mathrm{V}$ & + & + & + & + & + & + & + & + & + & + & + \\
\hline Glycogen & - & - & - & + & - & - & - & - & - & - & $\mathrm{V}$ & - & - \\
\hline DNA G $+C$ content $(\mathrm{mol} \%)$ & 45.6 & $43-45$ & 42.7 & 43 & $42-43$ & 41 & $40-43$ & $36-38$ & 37.3 & $39.3-30$ & $39.9-40.5$ & 39.8 & $44-44.2$ \\
\hline
\end{tabular}

The $\mathrm{G}+\mathrm{C}$ content of the genomic DNA of the strain Jip $14^{\mathrm{T}}$ was $45.6 \mathrm{~mol} \%$, which is slightly higher than values reported for other species in the family Sphingobacteriaceae. Yabuuchi et al. (1983) reported that members of the genus Sphingobacterium, the type genus of the family, showed DNA G + C contents of $39-42 \mathrm{~mol} \%$. 
Table 2. Cellular fatty acid profiles of strain Jip $14^{\top}$, Pedobacter species and other related species

Strains: 1, strain Jip $14^{\mathrm{T}}$; 2, Pedobacter africanus LMG $10353^{\mathrm{T}} ; 3$, Pedobacter caeni LMG $22862^{\mathrm{T}}$; 4, Pedobacter cryoconitis DSM 14825 $5^{\mathrm{T}}$; 5 , Pedobacter heparinus LMG $10339^{\mathrm{T}}$; 6, Pedobacter himalayensis HHS $22^{\mathrm{T}} ; 7$, Pedobacter piscium LMG 140 ${ }^{\mathrm{T}}$; 8, Pedobacter saltans LMG $10337^{\mathrm{T}}$;

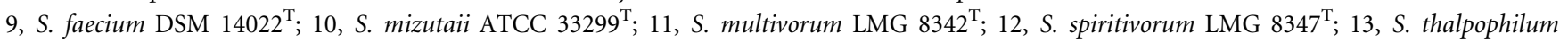
LMG $11520^{\mathrm{T}}$. Data for reference strains were taken from Steyn et al. (1998), with the exception of Pedobacter caeni LMG 22862 ${ }^{\mathrm{T}}$ (data from Vanparys et al., 2005) and Pedobacter himalayensis HHS $22^{\mathrm{T}}$ (Shivaji et al., 2005). For unsaturated fatty acids, the position of the double bond is located by counting from the methyl $(\omega)$ end of the carbon chain; cis isomers are indicated by the suffix $c$. Values are percentages of total fatty acids; tr, trace amount; ECL, equivalent chain length.

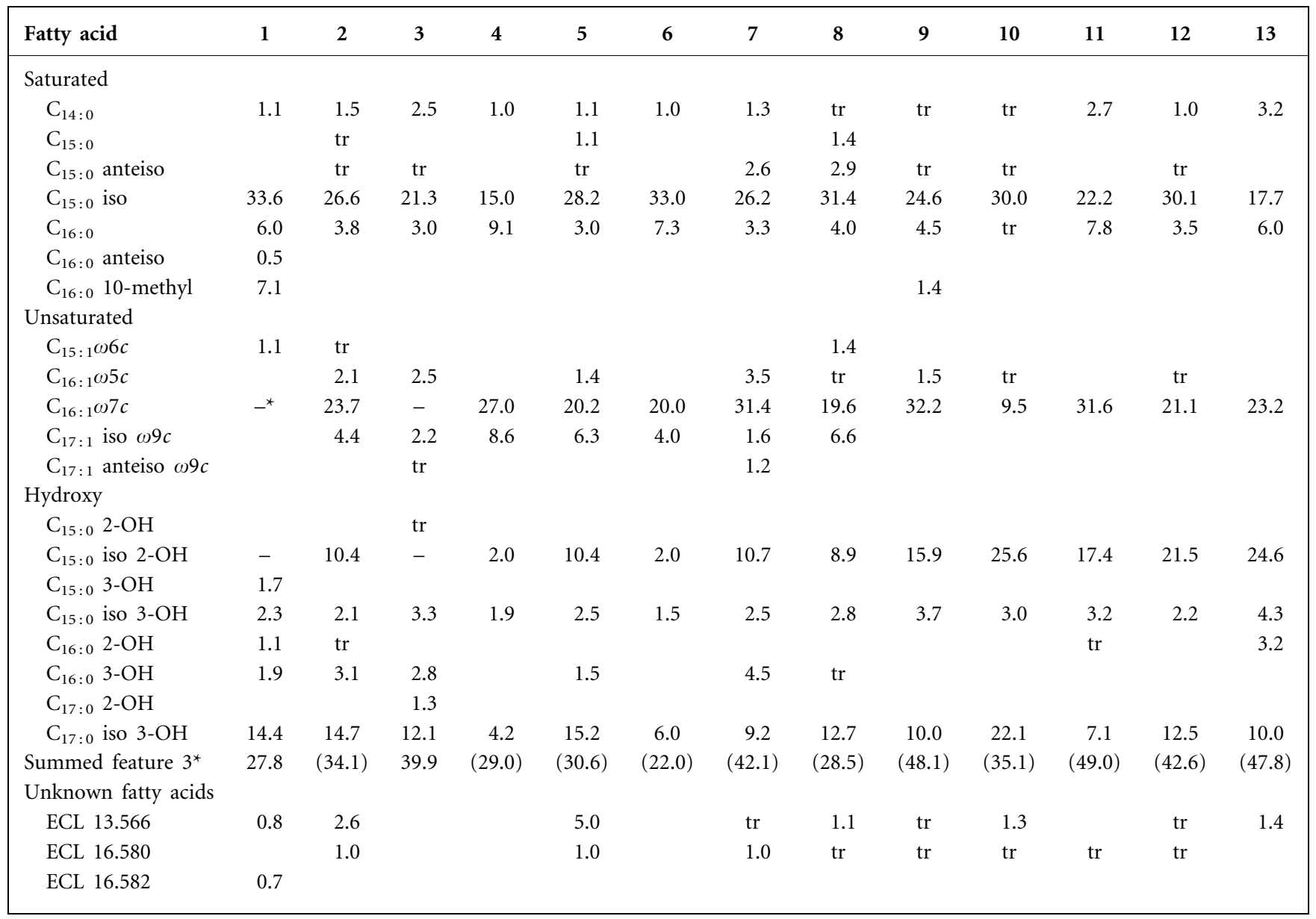

${ }^{*}$ Summed feature 3 contains $\mathrm{C}_{15: 0}$ iso $2-\mathrm{OH}$ and/or $\mathrm{C}_{16: 1} \omega 7 \mathrm{c}$, which could not be separated reliably by GLC with the Microbial Identification System. Steyn et al. (1998) and Shivaji et al. (2005) used a more polar chromatographic system to separate these two components; their combined contents are given in parentheses.

On the basis of the phenotypic, chemotaxonomic and phylogenetic data, we conclude that strain Jip $14^{\mathrm{T}}$ is a member of a novel genus and species of the family Sphingobacteriaceae, for which the name Parapedobacter koreensis gen. nov., sp. nov. is proposed.

\section{Description of Parapedobacter gen. nov.}

Parapedobacter (Pa.ra.pe'do.bac.ter. Gr. pref. para- like, beside; N.L. masc. n. Pedobacter a bacterial genus; N.L. masc. n. Parapedobacter like Pedobacter, referring to the close relationship to the genus).
Cells are Gram-negative. Oxidase- and catalase-positive. MK-7 is present in the respiratory chain. The major fatty acids are $\mathrm{C}_{15: 0}$ iso, $\mathrm{C}_{16: 0}, \mathrm{C}_{16: 0} 10$-methyl, $\mathrm{C}_{17: 0}$ iso $3-\mathrm{OH}$ and summed feature $3\left(\mathrm{C}_{15: 0}\right.$ iso $\left.2-\mathrm{OH} / \mathrm{C}_{16: 1} \omega 7 c\right)$. The major polyamine is homospermidine and sphingolipid is also detected. The type species is Parapedobacter koreensis.

\section{Description of Parapedobacter koreensis sp. nov.}

Parapedobacter koreensis (ko.re.en'sis. N.L. masc. adj. koreensis of Korea, from where the type strain was isolated). 


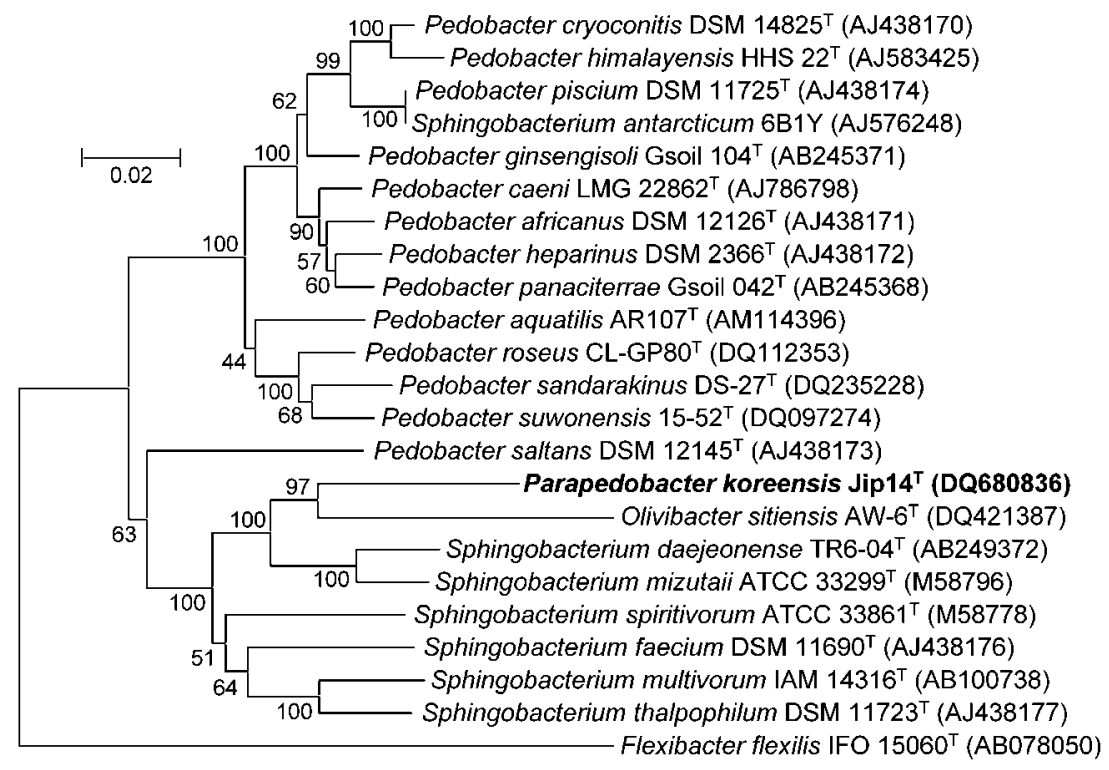

Fig. 1. Phylogenetic tree based on $16 \mathrm{~S}$ rRNA gene sequences, showing the phylogenetic relationships between strain Jip $14^{\top}$ and Pedobacter and Sphingobacterium species. The neighbour-joining method was used. Bar, 0.02 substitutions per nucleotide position.

Displays the following properties in addition to those given in the genus description. Cells are aerobic, non-motile rods after growth on R2A agar (Difco) at $30^{\circ} \mathrm{C}$ for 5 days. Colonies grown on R2A agar for 5 days are white and circular. Optimal growth temperature is $37^{\circ} \mathrm{C}$. Grows in a salt concentration of $3 \%$, but it cannot grow above $4 \%$. Produces $N$-acetyl- $\beta$-glucosaminidase, acid and alkaline phosphatases, $\alpha$-chymotrypsin, trypsin, $\alpha$ - and $\beta$-glucosidases, $\alpha$ - and $\beta$-galactosidases and cystine, leucine and valine arylamidases but does not produce arginine dihydrolase, esterase, $\alpha$-fucosidase, $\beta$-glucuronidase, lipase, $\alpha$-mannosidase, naphthol-AS-BI-phosphohydrolase, protease or urease. Assimilates gluconate, L-fucose, D-glucose, D-maltose, Dmannose, D-ribose, sucrose, inositol, D-mannitol, D-sorbitol, L-serine, $N$-acetyl-D-glucosamine and salicin. Does not assimilate 2-ketogluconate, 3-hydroxybenzoate, 3-hydroxybutyrate, 4-hydroxybenzoate, 5-ketogluconate, acetate, adipate, caprate, citrate, itaconate, lactate, L-malate, malonate, phenylacetate, propionate, suberate, $\mathrm{n}$-valerate, $\mathrm{L}$-arabinose, D-melibiose, L-rhamnose, L-alanine, L-histidine, L-proline or glycogen. The DNA $\mathrm{G}+\mathrm{C}$ content of the type strain is $45.6 \mathrm{~mol} \%$ as determined by HPLC. The major cellular fatty acids are $\mathrm{C}_{15: 0}$ iso (33.57\%), $\mathrm{C}_{16: 0}(6.02 \%), \mathrm{C}_{16: 0} 10$-methyl $(7.08 \%), \mathrm{C}_{17: 0}$ iso $3-\mathrm{OH}(14.39 \%)$ and summed feature 3 $(27.8 \%)$. Minor components $\mathrm{C}_{14: 0}(1.12 \%), \mathrm{C}_{16: 0}$ anteiso $(0.54 \%), \mathrm{C}_{15: 1} \omega 6 c(1.05 \%), \mathrm{C}_{15: 0} 3-\mathrm{OH}(1.7 \%), \mathrm{C}_{15: 0}$ iso $3-\mathrm{OH}(2.34 \%), \mathrm{C}_{16: 0} 2-\mathrm{OH}(1.06 \%)$ and $\mathrm{C}_{16: 0} 3-\mathrm{OH}$ $(1.9 \%)$ are also present. Does not reduce nitrate to nitrite or nitrogen gas.

The type strain, Jip $14^{\mathrm{T}}\left(=\right.$ KCTC $\left.12643^{\mathrm{T}}=\mathrm{LMG} 23493^{\mathrm{T}}\right)$, was isolated from dried rice straw in South Korea.

\section{Acknowledgements}

This work was supported by the Korea Research Foundation Grant funded by the Korean Government (MOEHRD) (KRF-2006-351C00032).

\section{References}

Buck, J. D. (1982). Nonstaining (KOH) method for determination of Gram reactions of marine bacteria. Appl Environ Microbiol 44, 992-993.

Busse, J. \& Auling, G. (1988). Polyamine pattern as a chemotaxonomic marker within the Proteobacteria. Syst Appl Microbiol 11, 1-8.

Cappuccino, J. G. \& Sherman, N. (2002). Microbiology: a Laboratory Manual, 6th edn. Menlo Park, CA: Pearson Education/Benjamin Cummings.

Collins, M. D. \& Jones, D. (1981). Distribution of isoprenoid quinone structural types in bacteria and their taxonomic implications. Microbiol Rev 45, 316-354.

Felsenstein, J. (1985). Confidence limit on phylogenies: an approach using the bootstrap. Evolution 39, 783-791.

Gallego, V., Garcia, M. T. \& Ventosa, A. (2006). Pedobacter aquatilis sp. nov., isolated from drinking water, and emended description of the genus Pedobacter. Int J Syst Evol Microbiol 56, 1853-1858.

Hall, T. A. (1999). BioEdit: a user-friendly biological sequence alignment editor and analysis program for Windows 95/98/NT. Nucleic Acids Symp Ser 41, 95-98.

Holmes, B., Weaver, R. E., Steigerwalt, A. G. \& Brenner, D. J. (1988). A taxonomic study of Flavobacterium spiritivorum and Sphingobacterium mizutae: proposal of Flavobacterium yabuuchiae sp. nov. and Flavobacterium mizutaii comb. nov. Int J Syst Bacteriol 38, 348-353.

Hwang, C. Y., Choi, D. H. \& Cho, B. C. (2006). Pedobacter roseus sp. nov., isolated from a hypertrophic pond, and emended description of the genus Pedobacter. Int J Syst Evol Microbiol 56, 1831-1836.

Kim, M. K., Im, W.-T., Ohta, H., Lee, M. \& Lee, S.-T. (2005). Sphingopyxis granuli sp. nov., a $\beta$-glucosidase-producing bacterium in the family Sphingomonadaceae in $\alpha-4$ subclass of the Proteobacteria. J Microbiol 43, 152-157.

Kim, K.-H., Ten, L. N., Liu, Q.-M., Im, W.-T. \& Lee, S.-T. (2006). Sphingobacterium daejeonense sp. nov., isolated from a compost sample. Int J Syst Evol Microbiol 56, 2031-2036.

Kimura, M. (1983). The Neutral Theory of Molecular Evolution. Cambridge: Cambridge University Press.

Kumar, S., Tamura, K., Jakobsen, I. B. \& Nei, M. (2001). MEGA2: molecular evolutionary genetics analysis software. Bioinformatics 17, 1244-1245. 
Kwon, S.-W., Kim, B. Y., Lee, K.-H., Jang, K.-Y., Seok, S.-J., Kwon, J.-S., Kim, W.-G. \& Weon, H. Y. (2007). Pedobacter suwonensis sp. nov., isolated from the rhizosphere of Chinese cabbage (Brassica campestris). Int J Syst Evol Microbiol 57, 480-484.

Margesin, R., Spröer, C., Schumann, P. \& Schinner, F. (2003). Pedobacter cryoconitis sp. nov., a facultative psychrophile from alpine glacier cryoconite. Int J Syst Evol Microbiol 53, 1291-1296.

Mesbah, M., Premachandran, U. \& Whitman, W. B. (1989). Precise measurement of the $\mathrm{G}+\mathrm{C}$ content of deoxyribonucleic acid by highperformance liquid chromatography. Int J Syst Bacteriol 39, 159-167.

Minnikin, D. E., O’Donnell, A. G., Goodfellow, M., Alderson, G., Athalye, M., Schaal, K. \& Parlett, J. H. (1984). An integrated procedure for the extraction of isoprenoid quinones and polar lipids. J Microbiol Methods 2, 233-241.

Saitou, N. \& Nei, M. (1987). The neighbor-joining method: a new method for reconstructing phylogenetic trees. Mol Biol Evol 4, 406-425.

Sasser, M. (1990). Identification of bacteria by gas chromatography of cellular fatty acids. MIDI Technical Note 101. Newark, DE: MIDI Inc.

Schenkel, E., Berlaimont, V., Dubois, J., Helson-Cambier, M. \& Hanocq, M. (1995). Improved high-performance liquid chromatographic method for the determination of polyamines as their benzoylated derivatives: application to P388 cancer cells. J Chromatogr B Biomed Appl 668, 189-197.

Shin, Y. K., Lee, J.-S., Chun, C. O., Kim, H.-J. \& Park, Y.-H. (1996). Isoprenoid quinone profiles of the Leclercia adecarboxylata KCTC $1036^{\mathrm{T}}$. J Microbiol Biotechnol 6, 68-69.

Shivaji, S., Ray, M. K., Rao, N. S., Saisree, L., Jagannadham, M. V., Kumar, G. S., Reddy, G. S. N. \& Bhargava, P. M. (1992) Sphingobacterium antarcticus sp. nov., a psychrotrophic bacterium from the soils of Schirmacher Oasis, Antarctica. Int J Syst Bacteriol 42, 102-106.

Shivaji, S., Chaturvedi, P., Reddy, G. S. N. \& Suresh, K. (2005). Pedobacter himalayensis sp. nov., from the Hamta glacier located in the Himalayan mountain ranges of India. Int J Syst Evol Microbiol 55, 1083-1088.

Steyn, P. L., Segers, P., Vancanneyt, M., Sandra, P., Kersters, K. \& Joubert, J. J. (1998). Classification of heparinolytic bacteria into a new genus, Pedobacter, comprising four species: Pedobacter heparinus comb. nov., Pedobacter piscium comb. nov., Pedobacter africanus sp. nov. and Pedobacter saltans sp. nov. Proposal of the family Sphingobacteriaceae fam. nov. Int J Syst Bacteriol 48, 165-177.

Takeuchi, M. \& Yokota, A. (1992). Proposals of Sphingobacterium faecium sp. nov., Sphingobacterium piscium sp. nov., Sphingobacterium heparinum comb. nov., Sphingobacterium thalpophilum comb. nov. and two genospecies of the genus Sphingobacterium, and synonymy of Flavobacterium yabuuchiae and Sphingobacterium spiritivorum. J Gen Appl Microbiol 38, 465-482.

Tamaoka, J. \& Komagata, K. (1984). Determination of DNA base composition by reversed phase high-performance liquid chromatography. FEMS Microbiol Lett 25, 125-128.

Ten, L. N., Liu, Q.-M., Im, W.-T., Lee, M., Yang, D.-C. \& Lee, S.-T. (2006). Pedobacter ginsengisoli sp. nov., a DNase-producing bacterium isolated from soil of a ginseng field in South Korea. Int J Syst Evol Microbiol 56, 2565-2570.

Thompson, J. D., Gibson, T. J., Plewniak, F., Jeanmougin, F. \& Higgins, D. G. (1997). The CLUSTAL_X windows interface: flexible strategies for multiple sequence alignment aided by quality analysis tools. Nucleic Acids Res 25, 4876-4882.

Vanparys, B., Kim, H., Lebbe, L. \& De Vos, P. (2005). Pedobacter caeni sp. nov., a novel species isolated from a nitrifying inoculum. Int J Syst Evol Microbiol 55, 1315-1318.

Weisburg, W. G., Barns, S. M., Pelletier, D. A. \& Lane, D. J. (1991). $16 \mathrm{~S}$ ribosomal DNA amplification for phylogenetic study. J Bacteriol 173, 697-703.

Yabuuchi, E., Kaneko, T., Yano, I., Moss, C. W. \& Miyoshi, N. (1983). Sphingobacterium gen. nov., Sphingobacterium spiritivorum comb. nov., Sphingobacterium multivorum comb. nov., Sphingobacterium mizutae sp. nov., and Flavobacterium indologenes sp. nov.: glucosenonfermenting gram-negative rods in CDC groups IIK-2 and IIb. Int $J$ Syst Bacteriol 33, 580-598.

Yoon, J.-H., Lee, M.-H., Kang, S.-J., Park, S.-Y. \& Oh, T.-K. (2006). Pedobacter sandarakinus sp. nov., isolated from soil. Int J Syst Evol Microbiol 56, 1273-1277.

Yoon, M.-H., Ten, L. N., Im, W.-T. \& Lee, S.-T. (2007). Pedobacter panaciterrae sp. nov., isolated from soil in South Korea. Int J Syst Evol Microbiol 57, 381-386. 